\title{
ACUMULANDO FORÇAS: LUTA PELA ALFORRIA E DEMANDAS POLÍTICAS NA CAPITANIA DE MINAS GERAIS \\ (1750-1808)
}

\author{
Marco Antonio Silveira \\ Doutor em História Social-FFLCH/USP \\ Prof. adjunto da Universidade Federal de Ouro Preto
}

\section{Resumo}

0 artigo tem por objetivo demonstrar que a expansão demográfica e econômica das populações de ascendência africana na Capitania de $\mathrm{M}$ inas $\mathrm{G}$ erais da segunda metade do século XVIII foi acompanhada da organização política de grupos de negros e mestiços em torno de irmandades e tropas. Valendo-se fundamental mente de petições enviadas ao Consel ho U Itramarino, o texto procura ressal tar a capacidade de tais grupos de, através da formulação de um discurso crítico, acumular força política.

\section{Pallavras-chaves}

Minas Gerais • alforria • ascensão social.

\section{Abstract}

The article aims to demonstrate how the demographic, as well as the economical expansion of African descent population in the Captaincy of Minas Gerais, along the second half of the eighteenth century, was accompanied by the political articulation of black and mestizo groups around brotherhoods and troops. Referring specifically to petitions sent to Conselho Ultramarino, it is the intent of this text to emphasize the ability of these groups to gather political strength through the formulation of a critical discourse.

\section{Keywords}

Minas Gerais • emancipation • social ascension. 
Alguns dos principais historiadores que se dedicaram ao estudo da vida confrarial na Minas setecentista ressaltaram que as irmandades de negros e mulatos, mesmo constituindo focos privilegiados de coesão grupal e política numa capitania desprovida de ordens regulares, mantiveram-se sempre nos limites estabelecidos pela ordem vigente. Dentre os fatores que justificariam esse quadro destacam-se geralmente o sucesso das estratégias regalistas de controle das associações religiosas, os conflitos existentes entre os diferentes grupos étnicos e raciais submetidos ao cativeiro e a inexistência de fontes que demonstrassem a organização de discursos ou movimentos de caráter contestatório. ${ }^{1}$ Este artigo, recorrendo a algumas petições enviadas ao Conselho Ultramarino, procura sugerir, embora de forma incipiente, que a significativa expansão demográfica e econômica das populações de ascendência africana no decorrer do século XVIII e a sua organização em torno de tropas e irmandades permitiram o desenvolvimento de um discurso identitário crítico em relação às condições políticas da época e à escravidão. O ponto de vista que fundamenta as observações a seguir é o de que a historiografia, ancorando suas análises na documentação oficial e numa expectativa finalista, deixou de compreender algumas das práticas e argumentações da época como estratégias factíveis e potencialmente radicais de luta política.

A intensa entrada de africanos na região das minas no período que se seguiu à descoberta do ouro redundou, como se sabe, na constituição do maior plantel de escravos da América portuguesa e, conseqüentemente, na formação de um expressivo contingente populacional composto por indivíduos negros. O número de escravos da Capitania que, na década de 1730, já havia atingido a cifra de cem mil homens e mulheres, permaneceu elevado durante toda a centúria, explicando em parte o fenômeno da multiplicação das irmandades de negros. No período colonial, foram instituídas pelo menos 62 associações dedicadas a Nossa Senhora do Rosário - um recorde dentre as inúmeras irmandades mineiras de então - e 20 à Senhora das Mercês. ${ }^{2}$ Um dos resultados mais significativos dessa rápida expansão demográfica, sentido de forma especial na segunda metade do

\footnotetext{
${ }^{1}$ Cf. SALLES, Fritz Teixeira de. Associações religiosas no ciclo do ouro. Belo Horizonte: Universidade de Minas Gerais, 1963; BARBOSA, Waldemar de Almeida. Negros e quilombos em Minas Gerais. Belo Horizonte, 1972; SCARANO, Julita. Devoção e escravidão. $2^{\mathrm{a}}$ ed. São Paulo: Cia. Editora Nacional, 1978 [1976]; BOSCHI, Caio César. Os leigos e o poder. São Paulo: Ática, 1986. ${ }^{2}$ Os números correspondem às irmandades identificadas por Caio César Boschi na extensa pesquisa em que se baseou seu livro. Cf. BOSCHI. Os leigos e o poder, op. cit., p. 187.
} 
século, foi o aumento contínuo e gradual da gente mestiça. Em 1776, os negros e os pardos da Capitania somavam, respectivamente, metade e um quarto da população total. ${ }^{3} \mathrm{O}$ impacto dos grupos mestiços na sociedade como um todo e nos diversos segmentos econômicos que a compunham esteve certamente na raiz do surgimento de irmandades como as de São José, São Francisco de Paula, São Gonçalo Garcia e da Arquiconfraria do Cordão.

O cenário caracterizado pela marcante presença de negros e pardos nas várias partes das Minas desdobrou-se na adoção, por parte da Coroa, de dois tipos distintos de política de controle social. De um lado, as autoridades promoveram e incentivaram constantemente o recurso a medidas estritamente repressivas que coibissem crimes, desordens e revoltas. É vasta a legislação que, derivada do pânico sofrido pelos habitantes de vilas e arraiais, almejou reprimir a vadiagem, o contrabando e as atividades de grupos aquilombados. De outro lado, porém, a Coroa desde cedo procurou intervir na organização da sociedade valendo-se de dispositivos institucionais e simbólicos aptos a promover uma integração administrada dos indivíduos negros, mestiços e forros que alcançavam algum sucesso nos seus afazeres. ${ }^{4}$ A política de integração patrocinada pela Coroa coadunava-se com o grau de diversificação alcançado pela economia das Minas e com o fato de que parte importante dos descendentes de africanos acomodava-se e, em alguns casos, prosperava com o exercício de atividades produtivas, comerciais e burocráticas. Assim, a par da guerra molecular que grassava cotidianamente nas Minas, forjaram-se meios através dos

\footnotetext{
${ }^{3}$ Os dados, retirados da conhecida Tábua dos habitantes da Capitania de Minas Gerais, são, como os levantamentos da mesma espécie feitos no século XVIII, questionáveis, mas permitem que se avalie o peso das populações negras e mestiças em Minas. Cf. MAXWELL, Kenneth. A devassa da devassa. Trad. Rio de Janeiro: Paz e Terra, 1985, p. 300. Embora a palavra "mestiço" pudesse designar outros grupos étnicos e raciais na Minas setecentista, ela será tomada aqui como sinônimo de "pardo", "mulato" e "cabra".

${ }^{4}$ Cf. SOUZA, Laura de Mello e. Desclassificados do ouro. $2^{\text {a }}$ ed., Rio de Janeiro: Graal, 1986; Norma e conflito. São Paulo: Cia. das Letras, Belo Horizonte: Ed. da UFMG, 1999; FURTADO, Júnia. O Livro da Capa Verde. São Paulo: Annablume, 1996; FIGUEIREDO, Luciano. O avesso da memória. Rio de Janeiro: José Olympio, Brasília: Edunb, 1993; GUIMARÃES, Carlos Magno. A negação da ordem escravista. São Paulo: Ícone, 1988; Escravismo e rebeldia escrava: quilombos nas Minas Gerais do século XVIII. In: SILVA, Maria Beatriz Nizza da (org.). Brasil. Colonização e escravidão. Rio de Janeiro: Nova Fronteira, 2000, p. 324-38; RUSSELL-WOOD, A. J. R. Autoridades ambivalentes: o Estado do Brasil e a contribuição africana para "a boa ordem na República”. In: SILVA, M. B. Nizza da, op. cit., p. 105-23; VALLEJOS, Julio Pinto. Slave control and slave resistance in Colonial Minas Gerais. In: PALMER, Colin A. (ed.). The worlds of unfree labour. Aldershot: Ashgate, 1998, p. 171-204.
} 
quais as lutas em torno da estratificação social foram travadas em termos mais jurídicos e políticos. As pressões por reconhecimento exercidas pela camada de negros e mestiços, expressas em inúmeras petições enviadas ao Conselho Ultramarino, demonstram vivamente esse aspecto. ${ }^{5}$ Em 1762, por exemplo, os camaristas da Vila do Príncipe se queixaram ao monarca pelo não cumprimento, em alguns anos anteriores, da ordem de 1726 que proibia aos mulatos o acesso aos principais ofícios concelhios. $\mathrm{O}$ desrespeito à ordem resultava, segundo os camaristas, de "[...] haverem subornos nas eleições, com empenhos de alguns que padecem essa nota $[\ldots]$ ". ${ }^{6}$

Conflitos dessa natureza, como foi sugerido acima, faziam sentido na época em decorrência do fortalecimento demográfico e político de alguns grupos de mestiços em Minas. Sua ascensão social e econômica passou a significar para os brancos uma ameaça concreta em função da concorrência que enfrentavam na disputa pelos recursos materiais e simbólicos disponíveis. Poucos anos antes da representação da Vila do Príncipe, os homens pardos da Confraria do Senhor São José de Vila Rica escreveram ao rei solicitando o direito de usar espadim à cinta. ${ }^{7}$ Uma dúvida surgira quando da divulgação na América da Pragmática de 24 de maio de 1749 , que proibiu a regalia a negros e pessoas de baixa condição, sem contudo fazer menção expressa ao caso dos pardos.

\footnotetext{
${ }^{5}$ Para uma análise mais extensa sobre a organização, entre a gente liberta e de ascendência africana, de formas políticas e jurídicas de luta social nas Minas, cf. SILVEIRA, Marco Antonio. Soberania e luta social: negros e mestiços libertos na Capitania de Minas Gerais (1709-63), mimeo. Nesse artigo são apresentadas e discutidas diversas petições enviadas ao Conselho Ultramarino em defesa dos interesses de negros, mestiços e forros.

${ }^{6}$ Representação dos oficiais da Câmara de Vila do Príncipe contra o casamento dos brancos com os mulatos e vice-versa, solicitando ordem régia sobre este assunto (28.04.1762) - Arquivo Histórico Ultramarino/Minas Gerais (AHU/MG), caixa 80, documento 32. John Russell-Wood descreve episódio parecido ocorrido alguns anos antes em Vila Rica: "Em 1748, o procurador do Senado de Vila Rica apresentou um protesto formal pelo fato de mulatos estarem servindo de juízes da vintena em algumas paróquias dos subúrbios da vila, e declarou que tais nomeações eram prejudiciais 'ao bem público'. Requereu que os nomeados fossem suspensos. O que é interessante é que tais nomeações não se deviam à falta de homens brancos ou a algum descuido. A seleção dos juízes era rigorosa [...] Os vereadores, a 26 de junho de 1748, não levaram em conta esta objeção baseados no fato de que os mulatos, se 'fossem homens de bom procedimento e não prejudicassem o bem comum, pudessem servir porque a bondade da lei não consiste no acidente mas sim no bom procedimento'. O Senado observou que a experiência mostrara que os brancos se recusavam a ocupar este cargo". RUSSELL-WOOD, A. J. R.. Autoridades ambivalentes, op. cit., p. 109-10. ${ }^{7}$ Requerimento dos homens pardos da Confraria de São José de Vila Rica das Minas solicitando o direito de usar espadim à cinta (06.03.1758) - AHU/MG, caixa 73, documento 20; Consulta do Conselho Ultramarino sobre a petição dos homens pardos da Confraria do Senhor São José de Vila Rica das Minas Gerais para poderem usar espadim (13.03.1758)-AHU/MG, caixa 73, documento 27.
} 
Os peticionários consideravam-se excluídos da proibição porque, além de não terem sido diretamente referidos na lei, eram

legítimos vassalos de VMaj e nacionais daqueles domínios, onde vivem com reto procedimento; uns são mestres aprovados pela Câmara da dita vila em seus ofícios mecânicos, e subordinados a estes trabalham vários oficiais e aprendizes; outros se vêem constituídos mestres em artes liberais, como os músicos, que o seu efetivo exercício e trabalho é pelos templos do Senhor e procissões públicas, onde certamente é grande indecência irem de capote, não se atrevendo vestir em corpo por se verem privados do adorno e compostura dos seus espadins, com que sempre se trataram; e finalmente outros, aspirando a mais, se acham mestres em gramática, cirurgia e medicina, e na honrosa ocupação de mineiros, sendo muitos destes filhos de homens nobres, que como tais são reconhecidos $[\ldots]^{8}$

O requerimento dos pardos de Vila Rica, embora atinente a uma lei definida em parte pela exclusão racial, destacava a emergência social e econômica dos grupos nele envolvidos e sua capacidade de organizar-se politicamente. Mais ainda, é de se notar o uso da Confraria de São José como instrumento de pressão social e política. No entanto, a petição parece reforçar a tese de que a concorrência social resultante da promoção de indivíduos de ascendência africana implicava também o estabelecimento de clivagens irreconciliáveis entre negros e pardos. ${ }^{9}$ A ausência de menção a africanos e crioulos pode ser explicada em boa medida pelas próprias circunstâncias da Pragmática que, de cara, havia excluído os negros do uso do espadim. Porém, os mestiços possuíam reivindicações muito particulares, já que, diferentemente dos negros, podiam valorizar o fato de serem filhos de brancos e, em alguns casos, de brancos nobres. Algumas de suas conquistas ou pretensões, como a de servir o posto de juiz de ofício, tornar-se vintena ou até ocupar os principais cargos concelhios (mesmo por via de suborno), achavam-se bem mais distantes de crioulos e principalmen-

\footnotetext{
${ }^{8}$ Requerimento dos homens pardos da Confraria de São José de Vila Rica das Minas solicitando o direito de usar espadim à cinta (06.03.1758).

${ }^{9}$ Sobre os conflitos entre africanos, crioulos e pardos, cf. REIS, João José e SILVA, Eduardo. Negociação e conflito. São Paulo: Cia. das Letras, 1989, p. 45, 54, 70, 102-3 e RUSSELL-WOOD. Escravos e libertos no Brasil colonial. Trad. Rio de Janeiro: Civilização Brasileira, 2005, p. 125, 323, 332. Sobre o contraponto entre escravos e libertos, cf. MATTOSO, Kátia de Queirós. Ser escravo no Brasil. $2^{\text {a }}$ ed. São Paulo: Brasiliense, 1988, cap. A mentalidade do libertando e a do liberto.
} 
te de africanos. Além disso, as clivagens no interior das populações mestiças também eram decisivas e baseavam-se em pelo menos três critérios distintos: a qualidade do ofício desempenhado, a propriedade e a ascendência. Afastar-se das atividades manuais e tornar-se um proprietário bem-sucedido, objetivos mais facilmente alcançados sob o patrocínio de um pai branco reputado, balizavam, em termos gerais, a melhor trajetória de branqueamento. Assim, percebe-se no requerimento dos irmãos de São José a indicação de quatro grupos diferentes, organizados em dois níveis. O primeiro, mais abaixo, constituía-se de mestres artesãos e de músicos, grupos alheios a funções vis porque, respectivamente, comandavam trabalhadores e dedicavam-se a uma arte liberal. O segundo, "aspirando a mais", era composto por mestres em gramática, cirurgia e medicina, bem como por mineiros, sendo muitos deles filhos de brancos nobres. Não por acaso, os conselheiros acataram o parecer do procurador da Fazenda, para quem os suplicantes não deveriam ser excluídos da Pragmática somente pela cor, devendo-se-lhes " [...] permitir ou negar o uso da espada segundo a vida e exercício que tiverem, de sorte que se reputem como os brancos e tragam espada os que não exercem ofício e emprego vil [...]". ${ }^{10}$

A reforma nas tropas de auxiliares no ano de 1766 ratificou a força social adquirida pelos mestiços, organizando-os em terços e reconhecendo o prestígio de alguns deles ao torná-los oficiais. ${ }^{11}$ Desde então, parte significativa dos documentos enviados ao Conselho Ultramarino dizia respeito a pedidos de concessão ou confirmação de patentes de homens pardos. Aliás, a freqüência com que o termo "pardo" começou a despontar nas fontes oficiais sugere que a conotação pejorativa sintetizada na palavra "mulato" vinha sendo posta à prova. Em agosto de 1783, o governador d. Rodrigo de Meneses, respondendo a uma solicitação do Conselho Ultramarino, informou sobre o estado do terço de infantaria dos homens pardos da Vila de São José dizendo que sua "[...] utilidade, e a de semelhantes corpos, é constante para a pronta execução das

\footnotetext{
${ }^{10}$ Consulta do Conselho Ultramarino sobre a petição dos homens pardos da Confraria do Senhor São José de Vila Rica das Minas Gerais para poderem usar espadim (13.03.1758).

${ }^{11}$ Segundo Maria Beatriz Nizza da Silva, a Carta régia de 22 de março de 1766, que abrangia a América portuguesa, "[...] reiterou a formação de terços auxiliares e de ordenanças, insistindo que todos os moradores, 'nobres, plebeus, brancos, mestiços, pretos ingénuos e libertos', servissem nas tropas auxiliares. Cada um dos terços seria disciplinado por um sargento-mor escolhido entre os oficiais da tropa paga, vencendo o mesmo soldo que receberia nas tropas regulares", In: SILVA, M. B. N. da Silva (coord.). Dicionário da história da colonização portuguesa no Brasil. Lisboa: Verbo, 1994, p. 601.
} 
ordens do serviço de V. Majestade". ${ }^{12}$ O mestre de campo do terço, Joaquim Pereira da Silva, era, segundo o governador, "[...] o homem da sua qualidade mais benemérito que tem aquela vila e termo [...]". ${ }^{13}$ Joaquim Pereira, antes de tornar-se mestre de campo, havia servido como capitão da ordenança do distrito dos Corgos e capela do padre Gaspar, no termo de São José, e como sargento-mor da infantaria auxiliar da mesma vila. ${ }^{14}$

De acordo com a lista de soldados enviada por d. Rodrigo, na qual o nome de cada um deles era acompanhado pela respectiva filiação e naturalidade, Joaquim Pereira, no referido ano de 1783, liderava, com a ajuda de oficiais menores, um total de 727 pardos, dos quais apenas 187 eram filhos de pais incógnitos e 15 eram expostos. Ou seja, mais de $70 \%$ dos soldados podiam identificar publicamente os pais, dado ainda mais importante quando se constata que mais de $80 \%$ deles tinham nascido no próprio termo da Vila de São José. Assim, o período em que a sociedade mineira pareceu sedimentar-se implicou também a constituição de grupos de pardos mais conscientes de seu valor e de sua identidade. Seria, contudo, exagero dizer que as medidas de integração administrada indicavam a vitória inquestionável das políticas da Coroa voltadas para a exploração colonial, para o domínio dos territórios americanos e para a acomodação de negros e mestiços. Alguns dos requerimentos enviados ao Conselho Ultramarino demonstram a formação entre eles de uma consciência política mais definida e de uma disposição maior para pressionar as autoridades. Sedimentação social, portanto, não significou necessariamente ordem e obediência, mas também conflito e questionamento. Dentre os temas que estavam em jogo encontravam-se o fim de determinadas restrições raciais, a valorização dos nascidos no país e a crítica a alguns dos limites da escravidão.

A intensidade e o alcance da pressão política exercida pelos mestiços de Minas, bem como o peso que nela cabia à identidade devocional, ficam patentes

\footnotetext{
${ }^{12}$ Carta de Rodrigo José de Meneses para d. Maria I informando sobre o estado do Terço de Infantaria Auxiliar dos Homens Pardos da Vila de São José (01.08.1783) - AHU/MG, caixa 119, documento 65 .

${ }^{13}$ Idem.

${ }^{14}$ Requerimento de Joaquim Pereira da Silva, capitão da Ordenança de Pé dos Homens Pardos Libertos do distrito dos Corgos e capela do pe. Gaspar, termo da Vila de São José, pedindo sua confirmação no exercício do referido posto (22.10.1776) - AHU/MG, caixa 110, documento 38; Requerimento de Joaquim Pereira da Silva, pedindo carta patente de confirmação do posto de mestre de campo do Terço de Infantaria Auxiliar dos Homens Pardos Libertos, do termo da Vila de São José do Rio das Mortes (19.06.1782) - AHU/MG, caixa 118, documento 46.
} 
no requerimento de 1786 dos pardos da irmandade de São Gonçalo Garcia de São João del Rei sobre o direito de poderem libertar as irmãs e os irmãos escravos. ${ }^{15}$ Os peticionários voltavam-se indignados contra os senhores mineiros que se negavam a alforriar seus cativos pardos mesmo quando estes possuíam o valor exigido. Os argumentos arrolados para contrariar tal atitude mostram o quanto se achavam informados alguns mestiços a respeito das questões políticas e judiciais de sua época, valendo-se para isso do contato com letrados. Em primeiro lugar, os irmãos de São Gonçalo Garcia procuraram contradizer a opinião de que ninguém era obrigado a vender coisa sua, ressaltando, de uma parte, que a liberdade era um direito natural e, de outra, que o direito de propriedade podia ser limitado quando pedia a pública utilidade. Nesses termos, a alforria na América deveria ser concedida a quem tivesse condições de pagá-la porque implicava "grande utilidade" aos domínios de Sua Majestade:

porque adquire novos vassalos úteis ao Estado, novos agricultores para as terras, novos povoadores para os sertões, novos descobridores para as minas de ouro, novos oficiais em todo o gênero de manufaturas para o comércio e, enfim, o benefício público para tantos infelizes que, podendo viver em liberdade sem prejuízo de seus senhores, estão em um cativeiro tanto mais penoso quanto é mais injusto. ${ }^{16}$

Em seguida, os peticionários argumentaram que, se as Ordenações obrigavam o senhor a vender seu escravo mouro para resgatar um cristão, o mesmo deveria ocorrer com o senhor do cativo cristão, pois o escravo mouro não merecia melhor tratamento do que aquele que vivia na cristandade. ${ }^{17}$ Ademais,

\footnotetext{
${ }^{15}$ Requerimento da corporação da Irmandade de São Gonçalo Garcia, ereta pelos pardos da Vila de São João del Rei, solicitando a d. Maria I a mercê de conceder à referida irmandade o poder de libertar os seus irmãos e irmãs que forem escravos, pagando uma indenização a seus donos (22.08.1786) - AHU/MG, caixa 125, documento 20. Este documento é parcialmente transcrito e comentado em BARBOSA, Waldemar de Almeida. Negros e quilombos em Minas Gerais. Belo Horizonte, 1972, p. 112-6.

${ }^{16}$ Requerimento da corporação da Irmandade de São Gonçalo Garcia, ereta pelos pardos da Vila de São João del Rei, solicitando a d. Maria I a mercê de conceder à referida irmandade o poder de libertar os seus irmãos e irmãs que forem escravos, pagando uma indenização a seus donos (22.08.1786). ${ }^{17}$ Os peticionários citaram o conhecido parágrafo 4 do título XI do livro $4^{\circ}$ das Ordenações que afirmava o seguinte: "E porque em favor da liberdade são muitas coisas outorgadas contra as regras gerais: se alguma pessoa tiver algum mouro cativo, o qual seja pedido para na verdade se haver de dar e resgatar algum cristão cativo em terra de mouros, que por tal mouro se haja de cobrar e remir: mandamos que a pessoa que tal mouro tiver seja obrigado de o vender e seja
} 
entre os próprios mouros, "com toda a sua barbaridade", o cativo cristão era logo libertado quando oferecia ao senhor o seu preço. Os irmãos de São Gonçalo lembraram ainda que reis de Portugal haviam concedido à Irmandade de Nossa Senhora do Rosário sediada na Corte o privilégio de libertar seus membros cativos, e isso em Lisboa, “[...] onde os cativeiros não eram tão freqüentes nem tão rigorosos $[\ldots] " .{ }^{18}$

Os argumentos apontados acima compunham um conjunto de recursos tradicionalmente aplicados nos debates em torno da escravidão nos domínios portugueses ultramarinos. Em linhas gerais, advinham das discussões teológicas, de regras estabelecidas nas Ordenações Filipinas ou, como no último caso, de legislação formulada por antigos monarcas. ${ }^{19} \mathrm{Um}$ outro argumento, porém, tinha a marca do seu tempo: a evocação da lei de 16 de janeiro de 1773 que procurou pôr fim à escravidão no Reino. As medidas de Sebastião José de Carvalho e Melo concernentes ao desenvolvimento industrial no Reino, à eliminação de resíduos feudais, à criação de companhias de comércio monopolistas e à ampliação do poder aquisitivo da população agrícola, entre outras, articulavam-se ao objetivo mais geral (mas nem por isso menos consistente) de inserir Portugal nos quadros da civilização. Nesse contexto, o ministro patrocinou a adoção de alvarás que pusessem fim à escravidão no Reino, embora não na América, procurando a um só tempo identificar a sociedade lusa com as formas civilizadas expressas

para isso pela Justiça constrangido". Esse título era comumente utilizado em processos judiciais envolvendo a liberdade de escravos em Minas. Cf. SILVEIRA, Marco Antonio. Herança maldita: a invenção da moral cativa na colônia (Vila Rica, 1780-1810). Pós-História. Assis: Unesp, volume 11, 2003, p. 61-90.

${ }^{18}$ Requerimento da corporação da Irmandade de São Gonçalo Garcia, ereta pelos pardos da Vila de São João del Rei, solicitando a d. Maria I a mercê de conceder à referida irmandade o poder de libertar os seus irmãos e irmãs que forem escravos, pagando uma indenização a seus donos (22.08.1786). ${ }^{19}$ A apropriação de argumentos letrados com o intuito de questionar alguns dos limites da escravidão não se circunscreveu ao século XVIII. Hebe Maria Matos analisa o caso do mestiço Lourenço da Silva Mendonça que, identificado como procurador de uma influente irmandade de pretos e de todos os homens pardos de Portugal, Castela e Brasil, apresentou-se ao papa em 1682 levando duas cartas de recomendação e duas petições. Nestas últimas, além de descrever torturas e maus-tratos que caracterizavam o "diabólico abuso da instituição da escravidão", argumentava que, embora o papa tivesse outrora permitido o cativeiro de pagãos, tal permissão não poderia se estender aos seus descendentes já nascidos no seio da cristandade. Cf. MATOS, Hebe Maria. A escravidão moderna nos quadros do Império português: o Antigo Regime em perspectiva atlântica. In: FRAGOSO, João, BICALHO, Maria Fernanda e GOUVÊA, Maria de Fátima (org.). O Antigo Regime nos trópicos. Rio de Janeiro: Civilização Brasileira, 2001, p. 143-62. 
pelos princípios iluministas da época e circunscrever práticas e instituições bárbaras às áreas coloniais. ${ }^{20}$

De fato, embora as idéias ilustradas tenham sido adaptadas à defesa da escravidão, o antiescravismo vinha ganhando consistência em países como a França, especialmente após a Revolução e, sobretudo, na Inglaterra. ${ }^{21}$ As estratégias pombalinas, conciliando a duras penas mercantilismo e ilustração, visavam à eliminação gradual do cativeiro no Reino sem que, no entanto, se colocasse em causa a sua legitimidade no Brasil. Assim, em 19 de setembro de 1761, um alvará proibiu o transporte de cativos da América, da África e da Ásia para Portugal, tornando obrigatória a concessão da alforria nos casos em que a lei fosse desrespeitada. Alguns anos mais tarde, em 16 de janeiro de 1773, um novo alvará determinou que os escravos cujas mães e avós também haviam sido escravas permanecessem sob cativeiro, mas que aqueles cuja escravidão viesse das bisavós fossem declarados livres. Por sua vez, as crianças que nascessem de escravas da data da lei em diante também seriam declaradas livres. Ademais, todos os indivíduos alforriados por determinação do alvará se achariam hábeis para quaisquer ofícios, honras e dignidades, não padecendo a

\footnotetext{
${ }^{20}$ Para uma revisão historiográfica sobre a abolição em Portugal, em que são questionadas as hipóteses de que almejaria o desenvolvimento industrial do Reino ou o suprimento de escravos para as colônias, cf. SILVA, Luiz Geraldo. Esperança de liberdade. Interpretações populares da abolição ilustrada (1773-1774). Revista de História. São Paulo: Departamento de História/USP, 2001, n. 144, p. 107-49. Para o autor, "Ao que parece, as Luzes chegaram a Portugal no século XVIII como uma maneira de ajustar o velho Reino em termos de paridade com as 'Cortes polidas' da Europa; nesse caso, 'civilizar' o corpo social significava extirpar a anômala instituição do escravismo, diminuir os contrastes sociais, bem como expulsar para a periferia do império, para o mundo não civilizado, as formas de sujeição pessoal que deveriam tão somente impulsionar o comércio e a produção coloniais. O mais importante era Portugal, finalmente, graças às Luzes, encontrar-se com a Europa, e não mais ter sua população vista como os cafres daquele continente, tal como formulou, no século XVII, o Padre Antônio Vieira" (p. 116). Cf. ainda NOVAIS, Fernando A. A extinção da escravatura em Portugal no quadro da política pombalina. In: Aproximações. São Paulo: Cosac Naify, 2005, p. 83-103; SCHWARTZ, Stuart. Segredos internos. Trad. São Paulo: Cia. das Letras, 1988, p. 384. Renato Pinto Venâncio, por sua vez, questiona tanto o caráter abolicionista das medidas pombalinas quanto sua aplicação prática. Cf. Pombal aboliu a escravidão em Portugal? Uma sondagem nos registros de óbitos da Sé de Lisboa. In : Anais da XXIV Reunião da Sociedade Brasileira de Pesquisa Histórica. Curitiba/PR, 2004, p. 33-6. Para Venâncio, “[...] é absurdo afirmar que Pombal extinguiu a escravidão em Portugal, ou mesmo que houvesse uma deliberada política visando alcançar tal objetivo" (p. 34).

${ }^{21}$ Cf. DAVIS, David Brion. El problema de la esclavitud en la cultura occidental. Trad. Buenos Aires: Paidós, 1968, em especial capítulos XIII e XIV; MARQUESE, Rafael B. Feitores do corpo, missionários da mente. São Paulo: Cia. das Letras, 2004, em especial a parte II, A teoria ilustrada da administração de escravos.
} 
nota de libertos. ${ }^{22}$ Em outras palavras, a lei de 1773 extinguiu a perpetuidade do cativeiro e divisou a eliminação da categoria de liberto em Portugal. Entre as justificativas para a decisão estava a de que a infâmia da escravidão não poderia alcançar os descendentes além do termo fixado pelas leis nos casos de crimes de lesa-majestade. Como no capítulo das Ordenações relativo a tais delitos as penas e a infâmia recaíam sobre os filhos e os netos somente, parecia um excesso não conceder a liberdade aos bisnetos de escravas. ${ }^{23}$

A razão de Estado explica as contradições da lei de 1773 quando confrontada à situação vigente no Brasil, pois muitos dos argumentos que embasavam a sua aplicação em Portugal poderiam também ser apropriados na América. ${ }^{24}$ O que estava em jogo, evidentemente, era o fato de que a política pombalina pressupunha a eficiência de uma exploração colonial fundada no cativeiro. Tais contradições, contudo, não passaram despercebidas aos peticionários de São Gonçalo Garcia e aos letrados que os auxiliaram. O argumento de sua petição era o de que muitos dos pardos cujos senhores recusavam alforriar

deviam ser compreendidos na lei de dezesseis de janeiro de 1773, por serem escravos já desde o terceiro, quarto e quinto avô, não lhe[s] valendo o indulto da mesma lei por ser nestas infelicíssimas capitanias interpretada por homens cheios de ambição, ricos, poderosos e que ocupam os cargos públicos e da justiça, os quais querem e decidem que só para os Algarves se publicou a referida lei (como se a razão nela não fosse idêntica nas províncias de Portugal e nas capitanias da América). ${ }^{25}$

Ainda que se deva sempre evitar o anacronismo de atribuir, aos homens e às mulheres do passado, interpretações do presente, parece inverossímil que os peticionários desconhecessem em absoluto motivações de Estado por detrás das contradições apontadas. Seja como for, a tópica dos senhores ambiciosos

\footnotetext{
${ }^{22}$ NOVAIS, F. A., op. cit., p. 94-100.

${ }^{23} \mathrm{O}$ parágrafo 13 do título VI do livro $4^{\circ}$, depois de ordenar que os filhos dos criminosos de lesamajestade ficassem infamados para sempre, completa: "E esta pena haverão pela maldade que seu pai cometeu. E o mesmo será nos netos somente, cujo avô cometeu o dito crime".

${ }^{24}$ Segundo NOVAIS, F. A., op. cit., p. 94, referindo-se à legislação pombalina sobre a escravidão, "[...] não eram princípios éticos, mas a razão do Estado, que orientava a política ultramarina".

${ }^{25}$ Requerimento da corporação da Irmandade de São Gonçalo Garcia, ereta pelos pardos da Vila de São João del Rei, solicitando a d. Maria I a mercê de conceder à referida irmandade o poder de libertar os seus irmãos e irmãs que forem escravos, pagando uma indenização a seus donos (22.08.1786). Grifo meu.
} 
e enganadores abria outras trilhas de contestação. Além de, possivelmente, servirem como crítica disfarçada à política ultramarina da Coroa, ajudavam a explorar favoravelmente os discursos sobre o governo dos escravos.

No século XVIII, Jorge Benci, André João Antonil e Manoel Ribeiro Rocha haviam discursado sobre os modos pelos quais os senhores cristãos deviam tratar seus escravos. ${ }^{26}$ Como se sabe, seus textos fundavam-se na legitimidade do cativeiro enquanto instituição, avançando na crítica aos excessos praticados por senhores inescrupulosos. No último quartel da centúria, época em que se elaborou a petição dos irmãos de São Gonçalo Garcia, o debate sobre o governo dos escravos, em certa medida como resposta aos antiescravistas, havia incorporado alguns princípios ilustrados e em especial os conceitos de humanidade e de interesse. A defesa do direito que tinham todos os seres humanos de serem tratados com certa dignidade conjugou-se, assim, com a idéia de que a busca do interesse individual exigiria o controle das paixões e a adoção de atitudes racionais. ${ }^{27}$ Por ambos os motivos, o tratamento dos cativos demandaria cuidados e a recusa de atitudes movidas pelo ódio e pela cólera. É possível que esses novos lugares-comuns estivessem presentes no requerimento de 1786, no qual, por exemplo, atribuía-se a ausência de moderação dos castigos em Minas à "suma dureza e falta de humanidade dos tirânicos senhores". ${ }^{28}$ Por outro lado, a tese de que a libertação dos escravos capazes de comprar a alforria mostrava-se positiva ao Estado por gerar vassalos úteis parece demonstrar que os peticionários estavam atentos às mudanças nos paradigmas epistemológicos da época, calcadas na valorização de noções tais como as de utilidade e interesse. ${ }^{29}$

\footnotetext{
${ }^{26}$ BENCI, Jorge. Economia cristã dos senhores no governo dos escravos. São Paulo: Grijalbo, 1977; ANTONIL, André João. Cultura e opulência do Brasil. $3^{\text {a }}$ ed. Belo Horizonte: Itatiaia, São Paulo: Ed. da Universidade de São Paulo, 1982; ROCHA, Manoel Ribeiro. Etíope resgatado. Petrópolis: Vozes, 1992. Cf. MARQUESE, R. B., op. cit., parte I, A teoria cristã do governos dos escravos. ${ }^{27}$ Cf. MARQUESE, R. B., op. cit., p. 87-94.

${ }^{28}$ Requerimento da corporação da Irmandade de São Gonçalo Garcia, ereta pelos pardos da Vila de São João del Rei, solicitando a d. Maria I a mercê de conceder à referida irmandade o poder de libertar os seus irmãos e irmãs que forem escravos, pagando uma indenização a seus donos (22.08.1786). A lei de 1773, articulando antigas e novas concepções, criticava as "Pessoas tão faltas de sentimentos de Humanidade, e de Religião"; ao fazer referência à "nota distintiva de libertos", caracterizava-a como algo que "[...] a superstição dos Romanos estabeleceu nos seus costumes, e que a União Cristã, e a sociedade civil faz[em] hoje intolerável no Meu Reino, como o tem sido em todos os outros da Europa". Alvará de dezasseis de janeiro de mil setecentos e setenta e três. In: SILVA, Luiz Geraldo, op. cit., p. 145.

${ }^{29} \mathrm{Cf}$., sobre episódios da segunda metade dos setecentos, referentes à defesa de letrados ao direito de determinados cativos alcançarem a liberdade por possuírem recursos para comprá-la, SILVA,
} 
O certo é que, após a defesa da aplicação da lei de 1773 ao Brasil, seguiamse na petição de São Gonçalo algumas denúncias contra o comportamento abusivo dos senhores. A primeira delas dizia respeito aos açoites excessivos e às "prisões de ferros". A segunda era a de que muitos senhores não alforriavam suas escravas pardas porque queriam obrigá-las a viver com eles um concubinato involuntário. Na mesma linha, uma terceira denúncia se referia ao uso que os senhores faziam das mesmas pardas ao empurrá-las para uma vida escandalosa. Para isso, deixavam-nas à míngua, aproveitando-se depois dos lucros e dos filhos nascidos da prostituição. A maneira indecorosa com que os senhores se aproveitavam da coartação constituía uma quarta denúncia. Segundo os peticionários, os senhores concediam liberdade de movimento aos escravos pardos para que estes lhes pagassem, depois de um certo tempo, um valor bastante superior ao seu preço,

o que eles aceitam por amor da liberdade; e tanto que lhes chega a notícia de que o escravo tem adquirido alguma coisa considerável, o fazem tornar ao cativeiro, roubando-lhe tudo o que encontram, encobrindo estes furtos com a afetada razão de que tudo o que o escravo adquire é para seu senhor,

Maria Beatriz Nizza da. A luta pela alforria. In: SILVA, M. B. Nizza da (org.). Brasil. Colonização e escravidão, op. cit., p. 296-307. A autora menciona o caso de um negro forro de São Paulo, em 1789, que, desejando alforriar a mulher, enviou uma petição ao governador Melo Castro e Mendonça: "Mas, apesar da interferência da autoridade máxima da capitania, a senhora da escrava relutava em alforriá-la, o que levou Melo Castro e Mendonça a escrever ao ouvidor de Paranaguá: 'A justiça e a humanidade me fizeram interessar nesta alforria, tanto porque a escrava se achava judicialmente avaliada, como porque o marido se oferecia a depositar em Juízo a importância de sua avaliação'. E terminava dizendo ao ouvidor que se encarregasse da questão, 'fazendo entrar nesses corações ímpios sentimentos de compaixão e ternura por uma classe de indivíduos que Deus não deve fazer desgraçados, visto que em tudo o mais nos são semelhantes" (p. 300). O mesmo vocabulário foi utilizado num caso maranhense de 1774, no qual um mulato se via diante da resistência de seu senhor em aceitar a compra da liberdade: "Começa o ouvidor por falar dos sentimentos 'inteiramente contrários às leis da humanidade' expressos pelo senhor do escravo, para em seguida contrapor os conceitos de 'estado natural' e 'Direito das Gentes': 'Todos sabem que a escravidão é diametralmente oposta e repugnante à liberdade dos homens considerados segundo o seu estado natural e que eles têm um certo e incontestável direito para a poderem reivindicar'" (p. 301). Este último tópico, como se viu, foi expressamente apresentado pelos peticionários de São Gonçalo Garcia. Ressalte-se ainda a semelhança de seus argumentos sobre a utilidade dos vassalos com os apresentados na lei de 1773, que cita "[...] os prejuízos que resultam ao Estado de ter tantos Vassalos lesos, baldados, e inúteis, quantos são aqueles miseráveis, que a sua infeliz condição faz incapazes para os Ofícios públicos; para o Comércio; para a Agricultura; e para os tratos, e contratos de todas as espécies". Alvará de dezasseis de janeiro de mil setecentos e setenta e três. In: SILVA, Luiz Geraldo, op. cit., p. 145. 
quebrada assim a fé, a promessa [?], a palavra, a estipulação [....$^{30}$

Por fim, uma última denúncia era a de que, quando os escravos chegavam à velhice, após terem servido muitos anos a seus senhores, eram lançados fora de casa e obrigados a mendigar o seu sustento.

Os cinco argumentos dos peticionários de São Gonçalo Garcia - o apelo ao direito natural, a utilidade pública, os merecimentos do cristão, a obtenção do mesmo privilégio concedido ao Rosário de Lisboa e a aplicação da lei de 1773 no Brasil -, assim como as cinco denúncias - os castigos excessivos, o concubinato involuntário, a prostituição indesejada, a quebra do contrato de coartação e o abandono na velhice -, apontam, portanto, para a existência de um discurso sistematizado que expressava o ponto de vista de parte das populações escravas e libertas. Os brancos não mais monologavam. Certamente o que mais chama a atenção nesse discurso é como, apesar do uso de trâmites políticos e de opiniões convencionais, ele não deixava de explorar ambigüamente algumas contradições da instituição escravista. Atentos a isso, os conselheiros aprovaram o seguinte parecer do procurador da Fazenda:

Conheço que a favor da liberdade se concede algumas vezes poderem-se obrigar os senhores a venderem os escravos; porém, conheço também que, se se dar [sic] esta faculdade a algumas irmandades, resultam inquietações e prejuízos. Vejo o que muitas vezes sucede à América de se concorrerem as escravidões pelo triste motivo de se julgarem necessárias; contudo, não me parece conveniente conceder-se à irmandade suplicante a graça que pede, e somente que SMaj pode fazer-lhe a de lhe permitir que, constando e provando ela legitimamente que com algum escravo seu irmão pratica seu senhor algum dos excessos que se referem neste requerimento, possa obrigá-lo a que o venda por um preço justo e legítimo. ${ }^{31}$

A tese de que o cativeiro na América era um mal necessário permeou todo o debate sobre a escravidão quando este esteve sob a influência dos princípios

\footnotetext{
${ }^{30}$ Requerimento da corporação da Irmandade de São Gonçalo Garcia, ereta pelos pardos da Vila de São João del Rei, solicitando a d. Maria I a mercê de conceder à referida irmandade o poder de libertar os seus irmãos e irmãs que forem escravos, pagando uma indenização a seus donos (22.08.1786).

${ }^{31}$ Idem.
} 
iluministas, sendo constantemente evocado pelos críticos do antiescravismo. ${ }^{32}$ $\mathrm{O}$ procurador, nesse contexto, mostrou-se atento à necessidade de manter em pé a legitimidade do cativeiro no Novo Mundo, ratificando a idéia de que a alforria era dádiva e não direito. $\mathrm{O}$ conteúdo de seu parecer espelhava a ambigüidade contida na petição dos devotos de São Gonçalo que, por uma parte, evocavam tópicos concernentes ao bom governo dos escravos, mas, por outra, reforçavam a tese do direito natural à liberdade e demandavam a aplicação no Brasil de uma lei de caráter abolicionista. ${ }^{33}$ De toda forma, o fato é que o acesso de negros e mestiços ao universo dos letrados criou as condições para que eles travassem um debate com a Corte e com os brancos em geral. O uso que fizeram dos meios políticos convencionais e o afinco com que pleitearam mercês e privilégios não implicaram necessariamente uma adesão acrítica à ordem imposta pelo Estado luso. Identificar a participação nas instituições e nos mecanismos estatais da época como mera aceitação do status quo é esvaziar o significado cotidiano das lutas sociais. Olhar de longe, traçar a linha que levou a escravidão até o final do século XIX e concluir, por fim, pela inocuidade desse debate na Minas setecentista é certamente uma atitude anacrônica. Quando se analisam detidamente os inúmeros processos judiciais envolvendo escravos e os conteúdos de petições remetidas ao Conselho Ultramarino, vinculando-os com as relações sociais e institucionais que os perpassavam, parece emergir um quadro marcado pela recorrência de certos argumentos e pela adoção de estratégias de acumulação de forças.

\footnotetext{
${ }^{32}$ Cf. DAVIS, D. B., op. cit., MARQUESE, R. B., op. cit.; NEVES, Guilherme Pereira das. Pálidas e oblíquas luzes: J. J. da C. de Azeredo Coutinho e a Análise sobre a justiça do comércio do resgate dos escravos. In: SILVA, M. B. Nizza da Silva (org.). Brasil. Colonização e escravidão, op. cit., p. 349-70.

${ }^{33}$ Essa ambigüidade aparece também no uso das palavras "escravidão" e "escravidões", parecendo referir-se, respectivamente, a uma instituição e a tipos ou casos individuais. Nas primeiras linhas da lei de 1773, falava-se dos "[...] grandes inconvenientes, que a estes Reinos se seguiam de se perpetuar neles a Escravidão dos Homens pretos [...]"; mais abaixo, aludindo-se ao fato de alguns senhores lusos obrigarem suas cativas a terem filhos, destacava-se "[...] a grande indecência, que as ditas Escravidões inferem aos meus Vassalos [...]".Alvará de dezasseis de janeiro de mil setecentos e setenta e três In: SILVA, Luiz Geraldo, op. cit., p. 145. Dessa forma, para se acabar definitivamente com a "escravidão dos homens pretos" no Reino, era preciso atalhar as "escravidões" resultantes do nascimento de crianças cativas. Se a lei de 1761 havia tentado pôr fim à instituição escravista em Portugal constrangendo o tráfico negreiro, a de 1773 almejava consolidar tal intento pondo limites à reprodução natural do cativeiro. No caso do parecer referente à petição dos pardos de São Gonçalo, o procurador, captando sua ambigüidade, defendia a opinião de que permitir generalizadamente que as irmandades fossem autônomas para atalhar escravidões implicaria "inquietações e prejuízos" para a escravidão.
} 
Conquanto a petição de São Gonçalo Garcia dissesse respeito explicitamente às populações pardas, seus argumentos tinham um caráter mais geral e, por isso, alguns deles apareceram também em documentos em defesa de negros. Esse é o caso, por exemplo, das extraordinárias petições da década de 1750 elaboradas e levadas pessoalmente à Corte pelo crioulo José Inácio Marçal Coutinho, em defesa dos libertos da Capitania de Minas Gerais. ${ }^{34}$ Apesar das documentadas cizânias existentes, em vários lugares e épocas da colonização européia na América, entre pardos, crioulos e africanos de diferentes etnias, é digno de nota o ecletismo de algumas das petições do período, pois nelas, de um lado, as identidades forra e escrava apareciam acima das diferenças de qualidade e, de outro, a identidade devocional era colocada acima das próprias diferenças de condição. Parte das petições escritas em nome dos negros e mestiços de Minas Gerais foi provavelmente elaborada por letrados brancos. Se bem que nelas não haja referências explícitas a doutores, sua participação torna-se patente pela acuidade das teses jurídicas evocadas. Certamente parte desses letrados esteve a serviço de irmandades de africanos e de seus descendentes na América. As congregações de pretos, crioulos e pardos poderiam mais facilmente mobilizar os recursos necessários ao pagamento de advogados e dos trâmites burocráticos. Ainda que padrinhos, protetores e vizinhos pudessem patrocinar demandas individuais e coletivas, as irmandades e as tropas, de acordo com as informações contidas nos próprios requerimentos, pareciam consistir nas principais formas de apoio e organização das camadas de escravos e libertos. Representações individuais, como a de Manoel de Sousa Porto, morador na freguesia das Congonhas da Vila de Sabará, deixam implícita a presença de letrados. ${ }^{35}$ Manoel escreveu ao monarca em 1758 queixando-se de que, depois de servir por muitos anos a seu senhor, este se recusava a vendê-lo a uma liberta que pretendia alforriá-lo pelo expressivo valor de 200 oitavas de ouro para com ele se casar. Como era comum em casos relativos a cativeiro, o requerimento de Manoel de Sousa fez

\footnotetext{
${ }^{34}$ Requerimento dos crioulos, pretos e mestiços forros, moradores em Minas, pedindo a d. José I a concessão de privilégios vários, dentre eles o de poderem ser arregimentados e gozarem do tratamento e honra de que gozam os homens pretos de Pernambuco, Bahia e São Tomé (07.01.1756) -AHU/MG, caixa 69, documento 05; Requerimento de José Inácio Marçal Coutinho (17.08.1761) -AHU/MG, caixa 79, documento 15. Cf., sobre as referidas petições, SILVEIRA, Marco Antonio. Soberania e luta social, op. cit.

${ }^{35}$ Arquivo Público Mineiro, Seção Colonial, códice 126, p. 21s.
} 
menção "[...] às leis régias deste Reino que dizem respeito à liberdade [...]", mas foi também além, apresentando um outro argumento importante. ${ }^{36}$

Afirmando-se natural do gentio da Guiné, região da Costa da Mina, disse que fora "[...] enganado e vendido enganosamente [...]", e que viera parar na cidade da Bahia aos cinco anos, onde, na posse de segundo senhor, foi batizado e passou a viver segundo as obrigações de cristão. ${ }^{37}$ Pelas circunstâncias que lhe causaram a perda da liberdade, requeria então que o rei obrigasse o senhor a vendê-lo pelas 200 oitavas,

pois no comum sentir dos doutores, não se mostrando título ou origem legal e verdadeira da coisa possuída, fica o perseguidor sem domínio dela; e por estes termos parece não estar o suplicante obrigado ao rigor do dito cativeiro, aonde se acha e serve há mais de 20 anos, que na forma das Bulas Pontifícias bastava o tempo de dez anos. ${ }^{38}$

A petição de Manoel de Sousa, portanto, fazia uso das discussões sobre a legitimidade ou não do cativeiro, recuperando a tese de que, não tendo ele resultado de guerra justa, de venda por extrema necessidade ou do ventre de mãe escrava, dever-se-ia considerá-lo ilegítimo e devolver o injustiçado à liberdade. ${ }^{39}$ Algumas décadas mais tarde, como se viu, o eixo da discussão tenderia a deslocar-se contemplando a idéia de que o cativeiro era um mal necessário. Mas o requerimento, ao utilizar uma tese que objetivava justificar a posse de cativos, expunha abertamente suas contradições. O fato de o monarca ter despachado favoravelmente ao suplicante, mandando que fosse contemplado, depois de averiguada a veracidade das suas informações, sugere que esse tipo de argumentação letrada fazia parte do jogo, mas não exclui o papel que tais reivindicações exerciam na formação de uma certa consciência de direitos e identidades entre os negros e os mestiços de Minas. Pode-se mesmo propor - embora tal proposta

\footnotetext{
${ }^{36}$ Idem. Sobre o uso do recurso às petições por cativos e libertos, cf. RUSSELL-WOOD, A. J. R. . Vassalo e soberano: apelos extrajudiciais de africanos e de indivíduos de origem africana na América portuguesa. In: SILVA, Maria Beatriz Nizza da (coord.). Cultura portuguesa na Terra de Santa Cruz. Lisboa: Estampa, 1995, p. 215-33.

${ }^{37}$ Arquivo Público Mineiro, Seção Colonial, códice 126, p. 21 s.

${ }^{38}$ Idem.

${ }^{39} \mathrm{Cf}$., sobre o debate acerca da legitimidade da escravidão, ZERON, Carlos Alberto M. La Compagnie de Jésus et l'institution de l'esclavage au Brésil, tese de doutorado apresentada à ÉHESC, 1998.
} 
dependa de estudos mais aprofundados - que casos individuais como o de Manoel de Sousa Porto fossem apoiados pelas irmandades ou por outros patrocinadores pelo que significavam em termos de afirmação política.

A presença de letrados brancos, no entanto, não impediu, e talvez tenha mesmo estimulado, a existência de documentos que, se não foram diretamente escritos por alguns dos próprios interessados, pelo menos contaram com a participação efetiva deles. Além do caso de José Inácio Marçal Coutinho, há o exemplo da carta de 1796, do pardo Miguel Ferreira de Sousa, morador em Mariana, sobre as injustiças sofridas pelos homens pardos e pretos libertos da Capitania. ${ }^{40} \mathrm{O}$ missivista, no final do documento, pedia “[... ] perdão de alguma palavra mal dita por rudezia [sic] do meu juízo [...]", ${ }^{41}$ indicando ter participado mais de perto de sua elaboração. Miguel Ferreira retomou as tópicas relativas à utilidade dos serviços dos forros, lembrando que eles combatiam quilombolas e índios nos matos e descobriam o ouro e outras riquezas das Minas. Citou nominalmente os regimentos e terços de homens pardos e pretos auxiliares e de ordenanças que, desde a ordem régia de 22 de março de 1766, eram os que, fardados e armados à própria custa, defendiam as povoações, faziam diligências em lugares distantes como o Rio de Janeiro, São Paulo e Mato Grosso, e combatiam nas guerras contra os espanhóis. Mostrando-se conhecedor da conturbada conjuntura de poucos anos antes, Miguel Ferreira lembrou ainda que "[...] na classe dos referidos homens pardos e pretos nunca houveram rebeliões em coisa [?] alguma, nem ainda por leve imaginação em coisas de desobediências, inconfidência, respeito às leis de VMaj [...]". ${ }^{42}$ E lembrou os que exercitavam as "artes da música" nos festejos das aclamações de reis e rainhas e dos nascimentos dos infantes.

Apesar de todos os seus esforços, os libertos mineiros, segundo o missivista, não eram devidamente recompensados e reconhecidos. Quando requeriam

\footnotetext{
${ }^{40}$ Carta de Miguel Ferreira de Sousa, morador na cidade de Mariana, expondo a d. Maria I a situação dos homens pardos e pretos libertos que estão sujeitos a todos os serviços e perigos, pedindo para eles justiça" (19.06.1796) - AHU/MG, caixa 142, documento 23. Este documento foi, em diferentes perspectivas, discutido em SOUZA, Laura de Mello e. Coartação. Problemática e episódios referentes a Minas Gerais no século XVIII. In: Norma e conflito, Belo Horizonte: Ed. da UFMG, p. 151-74, e em GROSSI, Ramon Fernandes. O “dar o seu a cada um”, tese de doutorado apresentada à UFMG, Belo Horizonte, 2005, p. 205-39.

${ }^{41}$ Carta de Miguel Ferreira de Sousa, morador na cidade de Mariana, expondo a d. Maria I a situação dos homens pardos e pretos libertos que estão sujeitos a todos os serviços e perigos, pedindo para eles justiça (19.06.1796).

${ }^{42}$ Idem.
} 
“terras de planta" para nelas trabalharem, eram preteridos pelos homens brancos que nem ao menos lhes pagavam os salários. Não tinham acesso às ocupações honrosas da República, pois não lhes eram concedidos ofícios públicos, quer nas Câmaras, quer no Tribunal da Junta da Real Fazenda. Alguns escravos continuavam a viver em perpétuo cativeiro porque os brancos não queriam admitir que a lei de 1773, cuja cópia fora anexada, também cabia aos "pardos e pretos nacionais" da Capitania. E mesmo os que conseguiam com a ajuda dos pais comprar a liberdade por muito dinheiro, além de não serem admitidos nos empregos públicos, chegava a tal ponto a sua miséria que

nem sequer os admitem nas ordens $3^{\mathrm{a}} \mathrm{s}$ e irmandades do Sacramento e outras por modo de desprezo, e mal permitem a que os ditos tenham alguma irmandade separada, sem serem unidas com eles, e ainda algumas das ditas são regidas e administradas pelos mesmos homens brancos com o pretexto de zeladores, fundando seus zelos somente em guardarem os dinheiros das ditas irmandades, fazendo com os ditos dinheiros seus negócios, de sorte que alguns não dão contas e ficam as irmandades perdendo. ${ }^{43}$

Enfim, Miguel Ferreira retomou boa parte das tópicas gestadas no decorrer de todo o século XVIII, colocando-se um tom acima em suas reivindicações. Procurou caracterizar positivamente o grupo de libertos ao qual pertencia e considerou inaceitáveis as exclusões praticadas nas Câmaras e nas congregações religiosas dos brancos. As mudanças demográficas da segunda metade da centúria, geradoras da explosão do número de mestiços e forros em Minas, explicam em parte que, na década de 1790, a defesa do fim das formas mais arraigadas de segregação se tornasse possível. Mas a mudança do tom havia resultado também do acúmulo de forças no debate político das décadas anteriores. No centro desse debate achavam-se as tropas e algumas das irmandades de negros e mestiços da Capitania, constantemente citadas nas petições. A crítica de Miguel Ferreira à tentativa dos homens brancos de controlar as irmandades dos africanos e seus descendentes ajuda a compreender o significado mais profundo dos conflitos travados por seus dirigentes contra autoridades, capelães, vigários e outros indivíduos brancos. ${ }^{44}$ Muitas irmandades atuavam não apenas

\footnotetext{
${ }^{43}$ Idem.

${ }^{44} \mathrm{Cf}$., sobre os conflitos com corregedores e capelães, AGUIAR, Marcos Magalhães. Vila Rica dos confrades, dissertação de mestrado apresentada à USP, São Paulo, 1994.
} 
como meios de proteção e caridade junto a seus membros, mas também como instrumentos eficazes de pressão política e de luta social.

Ao requerimento de Miguel Ferreira - que, além da aplicação da lei de 1773 em Minas, pedia fossem os libertos devidamente remunerados - a Coroa também respondeu com a recusa. Para isso contribuiu sensivelmente a informação que Bernardo José de Lorena, governador da Capitania na época, remeteu a d. Rodrigo de Sousa Coutinho, afirmando que a carta era "tudo uma patranha e um bando de mentiras". ${ }^{45}$ De acordo com o governador, o alvará de 1773 nunca coubera ao Brasil, as sesmarias eram repartidas com igualdade, havendo nas Minas pardos com lavras e escravos que não sofriam nenhum tipo de embaraço. E desqualificou o peticionário classificando-o como " [...] um velho pobre e de má conduta, segundo me constou, que teve para si que em fazer tal petição não perdia senão uma folha de papel". ${ }^{46}$ Mas Bernardo José de Lorena talvez tenha exagerado na dose. Miguel Ferreira, como ele mesmo informou em sua petição, era capitão do terço dos pardos de Mariana, tendo servido como soldado na tropa paga do Rio de Janeiro. Alfabetizado, como tudo indica, provavelmente beneficiou-se do fato de ter tido como pai o capitão de ordenança Vicente Ferreira de Souza que servira como vereador na sede do Bispado mineiro. Pleiteou na mesma petição ser nomeado sargento-mor pago do terço a que pertencia. Numa devassa tirada contra ele pela mesma época, fica sugerida uma certa liderança de Miguel Ferreira, pois alguns escravos fugiram de seus donos ao saberem que ele havia mandado ao rei uma carta para se tornarem forros todos os que haviam servido mais de dez anos a seus senhores. ${ }^{47}$

\footnotetext{
${ }^{45}$ Carta de Bernardo José de Lorena a d. Rodrigo de Sousa Coutinho a respeito das queixas feitas pelos homens pardos e pretos libertos das Minas Gerais, o que tudo era uma mentira deles (17.04.1798) - AHU/MG, caixa 144, documento 21.

${ }^{46}$ Idem.

${ }^{47}$ Infelizmente, não tive acesso direto à devassa. Ela é descrita em GROSSI, R. F., op. cit., p. 215-9. Na carta de Miguel Ferreira de Sousa [...] (19.06.1796), não há nenhuma referência à tópica dos dez anos, embora, como sugere o caso de Manoel de Sousa Porto referido acima, ela circulasse entre cativos. Outras importantes informações sobre a pressão política de negros e mestiços podem ser colhidas no trabalho de Grossi. Sua linha interpretativa, contudo, diferente daquela aqui adotada, consiste em parte num bom contraponto às hipóteses tratadas neste artigo. Por exemplo, referindo-se a Miguel Ferreira, afirma o autor na p. 234: "Não acreditamos que ele estava dizendo que os homens com sangue africano deveriam receber um tratamento idêntico às pessoas brancas no momento da ocupação de 'ofícios públicos', mas que deveriam ter acesso a uma fatia desse universo, levando em conta os limites colocados à ascensão social da gente de 'cor' livre pela hierarquização via 'sangue' e ‘qualidade’. Em primeiro lugar, Miguel Ferreira deixava claro que os indivíduos da sua condição queriam distinguir-se socialmente através do recebimento de graças régias, de modo que eles se
} 
A petição de 1796, embora expressasse mais uma vez a pressão exercida por pardos instruídos, não se circunscrevia a este ou àquele grupo social em particular. Pelo contrário, estendia geralmente seus argumentos à defesa das populações negras e mestiças, sugerindo a existência de elementos identitários comuns acima dos critérios raciais normalmente adotados. É verdade que a valorização dos serviços praticados pelos libertos dava-se à custa da crítica e do combate aos quilombolas, o que aparentemente indica que os peticionários não colocavam em xeque a escravidão em si. Da mesma maneira, a defesa que faziam de sua importância para a manutenção da ordem aponta para uma certa aceitação das normas vigentes. Contudo, é inegável a radicalidade de algumas das demandas encontradas nas petições referidas, especialmente das que diziam respeito à lei de $1773 .{ }^{48} \mathrm{Se}$, como pediam os requerentes, as regras da abolição em Portugal fossem implantadas no Brasil, o número bastante significativo de escravos nelas contemplados implicaria um impacto nada desprezível nas

integravam à lógica social da diferenciação das pessoas via privilégios, acatando a concepção de que os homens eram efetivamente desiguais". SOUZA, Laura de Mello e, em Coartação..., op. cit., analisa o episódio de maneira mais nuançada: "Por fantasioso ou anedótico que seja, o episódio expressa o anseio corrente entre os homens de cor - tanto livres quanto escravos - por liberdade jurídica, acesso a cargos e honrarias. O que justificava tal anseio era o fato de cumprirem com suas obrigações civis. Nos documentos, não aparece o vocabulário cidadão, e é dicutível que o conceito fosse, então, de domínio comum. Em última instância, contudo, é de cidadania que se trata, ou melhor, da sua extensão aos homens de cor, livres ou escravos, que faziam a sua parte, cumprindo com suas obrigações". E conclui: "De fato, aqui residia o engodo e a contradição de uma ordem social que aceitava a alforria, promovia-a até, mas continuava considerando os forros como súditos subalternos, incapazes de governar as vilas ou integrar as irmandades mais prestigiadas - que seguiam sendo, pelo menos de direito, espaço privilegiado dos homens brancos" (p. 156). ${ }^{48}$ Maria Beatriz Nizza da Silva, em A luta pela alforria, op. cit., refere-se a um caso ocorrido em Salvador em que um homem pardo requeria sua liberdade por ter nascido depois de publicada a “novíssima lei” de 1773. No episódio do Maranhão mencionado acima, o ouvidor citou as "sábias leis que foram promulgadas em Portugal a 19 de setembro de 1761 e em 16 de janeiro do ano próximo passado (1773) pela qual foram habilitados para os empregos públicos todos os libertos por benefício do mesmo alvará" (p. 306). Stuart Schwartz, em Segredos internos, op. cit., p. 384, afirma que a abolição da escravidão no Reino "[...] provocou certa agitação entre os escravos" da América lusa, levando-os a reconhecer "[...] a inerente contradição da abolição do cativeiro em Portugal e da sua continuidade no Brasil. Ocasionalmente os escravos que viajavam de navio até a metrópole tentaram conseguir a liberdade. Uma declaração adicional de Pombal, em 1773, acarretou na Paraíba um movimento entre pardos escravos e livres, no qual procuraram a extensão da abolição ao Brasil". O evento da Paraíba, significativamente correlato ao que envolveu Miguel Ferreira em 1796 nas Minas, foi discutido por SILVA, Luiz Geraldo em Esperança de liberdade, op. cit.. O autor define os principais envolvidos no episódio como intermediários culturais, sendo todos pardos livres, com profissão e domínio sobre o ler e escrever. Entre as notícias impactantes que circularam na ocasião estava a de que “[...] os pretos haviam de ser admitidos ao serviço da Câmara” (p. 141). 
estruturas produtivas coloniais. Se fosse colocado em prática o argumento de que, em benefício da utilidade do Estado, deviam ser libertados os escravos capazes de pagar sua alforria, o domínio dos senhores sobre seus cativos ficaria irremediavelmente abalado. O fim das barreiras raciais que, pela lei e pelo costume, impediam o ingresso de descendentes de africanos nas Câmaras, na Real Fazenda ou nas ordens terceiras compostas pelos brancos, por sua vez, dissolveria algumas das bases que regulavam a estratificação social nas Minas. Enfim, se as petições traziam elementos de adesão, traziam também possibilidades de subversão. É essa ambigüidade que tem sido descurada por parte da historiografia. As pressões exercidas por grupos de negros e mestiços, muitas delas através de meios oficiais, podem ser encaradas como sinais de ingenuidade, hipocrisia ou adesão à ordem estabelecida, mas nada disso elimina o que representaram em termos de gestação de uma radicalidade potencial. ${ }^{49}$

Por esse motivo, o governador concluiu sua informação da seguinte maneira:

Passo agora a dizer, pelo que observei na primeira Junta de Justiças que fiz, que todos os réus foram pardos e pretos [...] Atenta, pois, a justa

\footnotetext{
${ }^{49}$ Nesse sentido, há que se relativizar o modelo explicativo que, concebendo a alforria não como negação, mas como parte constitutiva do quadro institucional escravista, vincula a continuidade deste no Brasil setecentista ao panorama caracterizado - para além da sistematização da legislação e dos instrumentos repressivos - por um menor desequilíbrio demográfico entre brancos e negros, pela ampliação das oportunidades de conquista da liberdade, pela constituição de importantes camadas de mestiços e libertos, e pelo estabelecimento de clivagens identitárias entre mulatos e crioulos, de um lado, e africanos, de outro. Cf. MARQUESE, Rafael de Bivar. A dinâmica da escravidão no Brasil. Resistência, tráfico negreiro e alforrias, séculos XVII a XIX. Novos Estudos. São Paulo: Cebrap, n. 74, mar/2006, p. 107-23; PATTERSON, Orlando. Slavery and social death. Cambridge: Harvard University Press, 1982; PAIVA, Eduardo França. Escravidão e universo cultural na colônia. Belo Horizonte: Ed. da UFMG, 2001. A perspectiva sistêmica e de longa duração adotada por R. B. Marquese permite que se perceba como as características citadas articularam-se no Brasil dos séculos XVIII e XIX de modo estrutural, produzindo um "quadro social escravista interno altamente estável". Contudo, essa aparência de estabilidade é certamente relativizada quando se adota uma perspectiva mais microscópica e apta a captar descontinuidades. O fato de padrões demográficos e aspectos socioeconômicos pulverizarem formas contestatórias mais ou menos radicais, como os quilombos ou o discurso peticionário, apenas nos informa que elas não podiam se organizar mais sistematicamente, e não que essa limitação implicasse necessariamente uma ordem altamente estável. A questão pode ser tratada do ponto de vista da contradição e da ambigüidade. Se houve, por um lado, institucionalização e amortecimento das tensões escravistas, houve também, por outro, um quadro caracterizado pela guerra molecular. Caso contrário, seria difícil compreender o pânico das autoridades da Capitania de Minas Gerais no decorrer dos Setecentos. O olhar da longa duração pode esvaziar o significado da violência cotidiana.
} 
lembrança de VExc dos fatos acontecidos nas Antilhas, e atendendo igualmente ao grandíssimo excesso em número que levam pardos e pretos sobre os brancos nesta Capitania, parece-me será muito prejudicial se SMaj favorecer mais em geral aquela casta de gente do que a tem já favorecido pelas suas sábias e justíssimas leis $[\ldots]^{50}$

O preconceito racial que estigmatizava negros e mestiços com a pecha da turbulência e da inconstância continuava vigoroso nos últimos anos dos Setecentos, reaparecendo o temor das autoridades de que se perdesse o controle dos domínios ultramarinos. O problema, porém, não podia mais ser colocado nos termos propostos pelo conde de Assumar ou por d. Lourenço de Almeida nas décadas de 1710 e 1720. Os exemplos das Antilhas ou da conspiração de 1798 na Bahia não equivaliam ao de Palmares. As idéias ilustradas, o antiescravismo, a Revolução Francesa, a Independência da América inglesa e as próprias mudanças de mentalidade entre os letrados lusos traziam novos ingredientes a velhas questões. Na conformação de um discurso próprio, grupos de escravos e libertos haviam acentuado o papel imprescindível para a conquista e a defesa do território colonial perpetrado pelos nacionais da terra. Se as camadas dirigentes da açucarocracia nordestina, especialmente a pernambucana, haviam desenvolvido no decorrer do século XVIII um nativismo que excluía a mestiçagem e subordinava os henriques, os descendentes de africanos da Capitania de Minas Gerais, a despeito de suas divergências, começaram a narrar uma história que os via também como protagonistas. ${ }^{51}$

O nativismo negro e mestiço do final dos Setecentos podia contar com um universo colonial mais rico e complexo, com a apropriação de discursos jesuíticos, jurídicos e ilustrados sobre a escravidão, com um perfil demográfico favorável, com a estruturação das tropas e das irmandades e com um cenário externo agitado. Essa constatação revela-se ainda mais importante quando se leva em conta que, na segunda metade dos Setecentos, discutiam-se nas Minas propostas reformistas de desenvolvimento das potencialidades locais e que, no

\footnotetext{
${ }^{50}$ Carta de Bernardo José de Lorena a d. Rodrigo de Sousa Coutinho a respeito das queixas feitas pelos homens pardos e pretos libertos das Minas Gerais, o que tudo era uma mentira deles (17.04.1798).

${ }^{51}$ Sobre o discurso nativista da açucarocracia, cf. MELLO, Evaldo Cabral de. Rubro veio. $2^{\mathrm{a}}$ ed. Rio de Janeiro: Topbooks, 1997, em especial os cap. À custa de nosso sangue, vidas e fazendas e No panteão restaurador. Para um exemplo da atuação política de negros e mestiços na Bahia do início do século XIX, cf. REIS, João José e SILVA, Eduardo Silva, op. cit., cap. O jogo duro do Dois de Julho: o "Partido Negro" na independência da Bahia.
} 
decorrer do século seguinte, o impacto das idéias liberais e dos debates sobre a formação do Estado Nacional brasileiro conduziu os grupos dirigentes a atentar ao caráter explosivo das pressões políticas exercidas pelos descendentes de africanos. ${ }^{52}$ Se os grupos dirigentes formularam, na Constituição de 1824 , uma definição de cidadania relativamente inclusiva que abarcava os libertos nascidos no Brasil, isso se devia não apenas à percepção de que as clivagens identitárias entre os africanos e seus descendentes haviam se tornado elemento importante para a manutenção do escravismo, mas também ao fato de que, nas décadas anteriores, crioulos e pardos, especialmente, vinham balizando uma luta política cotidiana definida pela acumulação de forças.

\section{Referências bibliográficas}

AGUIAR, Marcos Magalhães Aguiar. Vila Rica dos confrades. Dissertação de mestrado apresentada à USP, São Paulo, 1994.

ANTONIL, André João. Cultura e opulência do Brasil. $3^{\text {a }}$ ed. Belo Horizonte: Itatiaia, São Paulo: Ed. da Universidade de São Paulo, 1982.

BARBOSA, Waldemar de Almeida. Negros e quilombos em Minas Gerais. Belo Horizonte, 1972.

BENCI, Jorge. Economia cristã dos senhores no governo dos escravos. São Paulo: Grijalbo, 1977.

BOSCHI, Caio César. Os leigos e o poder. São Paulo: Ática, 1986.

DAVIS, David Brion. El problema de la esclavitud en la cultura occidental. Trad. Buenos Aires: Paidós, 1968.

FIGUEIREDO, Luciano. O avesso da memória. Rio de Janeiro: José Olympio, Brasília: Edunb, 1993.

FURTADO, Júnia. O Livro da Capa Verde. São Paulo: Annablume, 1996.

GROSSI, Ramon Fernandes. $O$ "dar o seu a cada um". Tese de doutorado apresentada à UFMG, Belo Horizonte, 2005, p. 205-39.

GUIMARÃES, Carlos Magno Guimarães. A negação da ordem escravista. São Paulo: Ícone, 1988.

Escravismo e rebeldia escrava: quilombos nas Minas Gerais do século XVIII. In: SILVA, Maria Beatriz Nizza da (org.). Brasil. Colonização e

\footnotetext{
${ }^{52}$ Cf. SILVA, Ana Rosa Cloclet da. Identidades políticas e a emergência do novo Estado nacional: o caso mineiro. In: JANCSÓ, István (org.). Independência do Brasil. História e historiografia. São Paulo: Hucitec, 2005, p. 515-555; Identidades em construção. O processo de politização das identidades coletivas em Minas Gerais, 1792 a 1831. Almanack Braziliense. São Paulo: IEB/USP, nº 1, mai./2005, p. 103-13.
} 
escravidão. Rio de Janeiro: Nova Fronteira, 2000, p. 324-38.

MARQUESE, Rafael Bivar. Feitores do corpo, missionários da mente. São Paulo: Cia. das Letras, 2004.

A dinâmica da escravidão no Brasil. Resistência, tráfico negreiro e alforrias, séculos XVII a XIX. Novos Estudos. São Paulo: Cebrap, n. 74, mar/2006, p. 107-23.

MATOS, Hebe Maria. A escravidão moderna nos quadros do Império português: o Antigo Regime em perspectiva atlântica. In: FRAGOSO, J., BICALHO, M. F. \& GOUVÊA, M. F. (org.). O Antigo Regime nos trópicos. Rio de Janeiro: Civilização Brasileira, 2001, p. 143-62.

MATTOSO, Kátia de Queirós. Ser escravo no Brasil. $2^{a}$ ed. São Paulo: Brasiliense, 1988.

MAXWELL, Kenneth. A devassa da devassa. Trad. Rio de Janeiro: Paz e Terra, 1985.

MELLO, Evaldo Cabral de. Rubro veio. $2^{\text {a }}$ ed., Rio de Janeiro: Topbooks, 1997.

NEVES, Guilherme Pereira das. Pálidas e oblíquas luzes: J. J. da C. de Azeredo Coutinho e a Análise sobre a justiça do comércio do resgate dos escravos. In: SILVA, Maria Beatriz Nizza da (org.). Brasil. Colonização e escravidão. Rio de Janeiro: Nova Fronteira, 2000, p. 349-70.

NOVAIS, Fernando A. A extinção da escravatura em Portugal no quadro da política pombalina. In: Aproximações. São Paulo: Cosac Naify, 2005, p. 83-103.

PAIVA, Eduardo França. Escravidão e universo cultural na colônia. Belo Horizonte: Ed. da UFMG, 2001.

PATTERSON, Orlando. Slavery and social death. Cambridge: Harvard University Press, 1982.

REIS, João José \& SILVA Eduardo. Negociação e conflito. São Paulo: Cia. das Letras, 1989.

ROCHA, Manoel Ribeiro. Etíope resgatado. Petrópolis: Vozes, 1992.

RUSSELL-WOOD, A. J. R. Vassalo e soberano: apelos extrajudiciais de africanos e de indivíduos de origem africana na América portuguesa. In: SILVA, Maria Beatriz Nizza da (coord.). Cultura portuguesa na Terra de Santa Cruz. Lisboa: Estampa, 1995, p. 215-33.

Autoridades ambivalentes: o Estado do Brasil e a contribuição africana para “a boa ordem na República". In: SILVA, Maria Beatriz Nizza da (org.). Brasil. Colonização e escravidão. Rio de Janeiro: Nova Fronteira, 2000, p. 105-23.

Escravos e libertos no Brasil colonial., Trad. Rio de Janeiro: Civilização Brasileira, 2005.

SALLES, Fritz Teixeira. Associações religiosas no ciclo do ouro. Belo Horizonte: Universidade de Minas Gerais, 1963. 
SCARANO, Julita. Devoção e escravidão. $2^{\mathrm{a}}$ ed. São Paulo: Cia. Editora Nacional, 1978 [1976].

SCHWARTZ, Stuart. Segredos internos. Trad. São Paulo: Cia. das Letras, 1988.

SILVA, Ana Rosa Cloclet. Identidades políticas e a emergência do novo Estado Nacional: o caso mineiro. In: JANCSÓ, István (org.). Independência do Brasil. História e historiografia. São Paulo: Hucitec, 2005, p. 515-555.

Identidades em construção. O processo de politização das identidades coletivas em Minas Gerais, 1792 a 1831. Almanack Braziliense. São Paulo: IEB/USP, no 1, mai./2005, p. 103-13.

SILVA, Luiz Geraldo. Esperança de liberdade. Interpretações populares da abolição ilustrada (1773-1774), Revista de História. São Paulo: Departamento de História/USP, 2001, n. 144, p. 107-49.

SILVA, Maria Beatriz Nizza da (coord.). Dicionário da história da colonização portuguesa no Brasil. Lisboa: Verbo, 1994.

SILVA, Maria Beatriz Nizza da Silva. (org.). Brasil. Colonização e escravidão. Rio de Janeiro: Nova Fronteira, 2000.

SILVA, Maria Beatriz Nizza da Silva. A luta pela alforria. In: SILVA, Maria Beatriz Nizza da (org.). Brasil. Colonização e escravidão. Rio de Janeiro: Nova Fronteira, 2000, p. 296-307.

SILVEIRA, Marco Antonio. Herança maldita: a invenção da moral cativa na colônia (Vila Rica, 1780-1810). Pós-História. Assis: Unesp, volume 11, 2003, p. 61-90. Soberania e luta social: negros e mestiços libertos na Capitania de Minas Gerais (1709-63), mimeo.

SOUZA, Laura de Mello e. Desclassificados do ouro. $2^{\mathrm{a}} \mathrm{ed}$. Rio de Janeiro: Graal, 1986. Norma e conflito. São Paulo: Cia. das Letras, Belo Horizonte: Ed. da UFMG, 1999.

VALLEJOS, Julio Pinto. Slave control and slave resistance in colonial Minas Gerais. In: PALMER, Colin A. (ed.). The worlds of unfree labour. Aldershot: Ashgate, 1998, p. 171-204.

VENÂNCIO, Renato Pinto. Pombal aboliu a escravidão em Portugal? Uma sondagem nos registros de óbitos da Sé de Lisboa. In : Anais da XXIV Reunião da Sociedade Brasileira de Pesquisa Histórica. Curitiba/PR, 2004, p. 33-6.

ZERON, Carlos Alberto M. La Compagnie de Jésus et l'institution de l'esclavage au Brésil. Tese de doutorado apresentada à ÉHESC, 1998. 